\title{
Biofilm formation analysis and molecular identification of copper-resistant bacteria isolated from PT Freeport Indonesia's tailings
}

\author{
Maria Massora ${ }^{1, *}$, Erni Martani ${ }^{2}$, Eko Sugiharto $^{3}$, Roberth Sarwom ${ }^{4}$, and Tumpal Sinaga ${ }^{4}$ \\ ${ }^{1}$ Biotechnology Study Program, Graduate School of Universitas Gadjah Mada, Jalan Teknika Utara, Depok, Sleman, Yogyakarta 55281, \\ Indonesia \\ ${ }^{2}$ Department of Microbiology, Faculty of Agriculture, Universitas Gadjah Mada, Jalan Flora, Yogyakarta 55281, Indonesia \\ ${ }^{3}$ Department of Chemistry, Faculty of Mathematics and Science, Universitas Gadjah Mada, Jalan Sekip Utara, Yogyakarta 55281, Indonesia \\ ${ }^{4}$ Environmental Department, PT Freeport Indonesia, Jalan Mandala Raya No. 1 OB-2, Timika 99920, Indonesia \\ *Corresponding author: maria.massora@mail.ugm.ac.id
}

\begin{abstract}
Copper is an essential macronutrient for living organisms. Nevertheless, at high concentrations, it is toxic to most forms of life, including microorganisms. In this research, we examined the biofilm formation ability and identified the molecular characteristics of copper-resistant bacteria isolated from PT Freeport Indonesia's tailings. Four bacteria isolates from PT Freeport Indonesia's tailings were used in this study. Qualitative analysis of biofilm formation by copper-resistant bacteria was performed using the Scanning Electron Microscopy (SEM) method and Microtiter Plate Biofilm Assay. The results showed that the $\mathrm{C} 53$ isolate could be categorized as a strong biofilm former, and three other isolates (C38, C40, and C43) as medium biofilm formers. The identity of the selected isolates was based on 16S rRNA gene sequence analysis: C38 isolate had a 99\% similarity to Bacillus cereus strain HM85, C43 isolate had a 99\% similarity to Bacillus subtilis strain EN16, C40 isolate had a 99\% similarity to Lycinibacillus fusiformis strain MB52, and C53 isolate had a 98\% similarity to Pseudomonas aeuruginosa strain GGRJ21. The capability of the C53 isolate to form strong biofilm can be exploited in bioremediation processes aiming to remove copper from tailings.
\end{abstract}

KEYWORDS $16 \mathrm{~S}$ rRNA; biofilm; copper resistant bacteria; minimum inhibitory concentration; scanning electron microscopy

\section{Introduction}

Microorganisms play an important role in the environmental fate of heavy metal toxic with a multiplicity of mechanisms causing transformation between insoluble and soluble forms. Although some heavy metals are essential trace elements, at high concentrations, they are toxic to all branches of life, including microbes, by forming complex compounds within the cell (Roy and Ganguly 2015).

Living organisms require copper as an essential micronutrient (Osredkar and Suskar 2011; Espírito Santo et al. 2014). However, at high concentrations, it is very toxic to most forms of life other than microorganisms (Andreazza et al. 2011; Espírito Santo et al. 2014). Mining activities in modern societies, extensive industrial use of copper, and its widespread use of pesticide in crop production are the major sources of copper pollution in soils and water (Andreazza et al. 2011). Soil bacteria are responsible for diverse ecological processes, such as biochemical cycling of the elements, plant growth, decomposition of organic matter, maintenance of soil structure, and detoxification (Chen et al. 2008; Desai et al. 2008). Copper accumulation could induce harmful effect to soil bacteria damaging the biological process and the soil quality (Chen et al. 2008; Freitas et al. 2009; He et al. 2009).

Bacteria that are resistant to toxic and recalcitrant chemicals can be isolated from polluted sites as well as natural soils and it can be used for bioremediation of environments contaminated by specific chemicals to which they are resistant (Umrania 2006; Chen et al. 2008; He et al. 2009; Jain et al. 2014). The ability of bacteria to form biofilm and grow in it as a microbial consortium is considered to be an important requirement for their survival under harsh environmental conditions. Microbes growing in biofilm community can perform some complex metabolic processes Biofilm-associated bacteria embedded in a matrix of Extracellular Polymeric Substance (EPS) (Annous et al. 2009), and the metabolic interaction among bacteria will enhance the degradation process (Cerca et al. 2005; Andersson et al. 2008; Annous et al. 2009; Khusnuryani et al. 2014). In this research, we examined biofilm forming ability and identified molecular characteristics of copper-resistant bacteria isolated from PT Freeport Indonesia's tailings. 


\section{Materials and methods}

\subsection{Bacterial cultures and growth medium}

The bacterial cultures used in this research were coded as C38, C40, C43, and C53. They were isolated from several sampling locations of PTFI's tailings in Timika, Papua (Massora et al. 2016). They were resistant to copper and had a minimum inhibitory concentration (MIC) of 400 $\mathrm{mg} / \mathrm{L}$ to $500 \mathrm{mg} / \mathrm{L}$ copper-sulfate. MIC of each bacterial isolates is shown in Table 1. These bacteria were grown in Luria-Bertani (LB) broth containing the following (per liter): tryptone $10 \mathrm{~g}$, yeast extract $5 \mathrm{~g}, \mathrm{NaCl} 10 \mathrm{~g}$, glucose $0.1 \mathrm{~g}$. LB medium was sterilized by autoclaving at $121^{\circ} \mathrm{C}$ for 20 min. After sterilization, Copper sulfate was added and the $\mathrm{pH}$ was adjusted to 7.0 (Andreazza et al. 2011).

\subsection{Qualitative analysis of biofilm formation}

The biofilm formation was analyzed using Scanning Electron Microscopy (SEM) in LPPT Universitas Gadjah Mada. The isolates of copper-resistant bacteria $\left(10^{6}\right.$ $\mathrm{CFU} / \mathrm{mL}$ ) were inoculated in Luria-Bertani broth and incubated overnight at room temperature on a shaker at 170 rpm. The coverslip was placed at the bottom of a Petri dish. Five (5) mL cultures of copper-resistant bacteria were placed on the coverslip surface until completely submerged and was incubated for $24 \mathrm{~h}$ at $37^{\circ} \mathrm{C}$ temperature. After incubation, the coverslip was added with $2 \%$ glutaraldehyde and stored at $4^{\circ} \mathrm{C}$ overnight. The sample in coverslip was prepared according to specimen preparation for SEM analysis (Ratnayake et al. 2012).

\subsection{Quantitative analysis of biofilm formation}

The quantitative analysis of biofilm formation ability by copper-resistant bacteria was modified from Mathur et al. (2006) and Merritt et al. (2011). The isolate of copperresistant bacteria $\left(10^{6} \mathrm{CFU} / \mathrm{mL}\right)$ was inoculated into LuriaBertani and incubated overnight at room temperature with a shaker at $170 \mathrm{rpm}$. After incubation, the isolate was added each $100 \mu \mathrm{L}$ into four wells of a microtiter plate. Microtiter plates were incubated at room temperature for 24 and $48 \mathrm{~h}$. Then, the isolates were removed and the plates were washed with aquadest. They were added with $125 \mu \mathrm{L}$ of $0.1 \%$ crystal violet solution for each well and stored at room temperature for 10 minutes. The plates were washed with aquadest after crystal violet solution was removed, and dried in inverse position for 1-2 weeks. When the

TABLE 1 MIC of copper-resistant bacterial isolates

\begin{tabular}{lll}
\hline No. & Isolates Codes & $\mathrm{MIC} \mathrm{CuSO}_{4}(\mathrm{mg} / \mathrm{L})$. \\
\hline 1 & 38 & 500 \\
2 & 40 & 500 \\
3 & 43 & 400 \\
4 & 53 & 400 \\
\hline
\end{tabular}

Source: Massora et al. 2016 plate dried, biofilm was diluted in $200 \mu \mathrm{L}$ of PBS, then it was stored for 10-15 minutes at room temperature. For quantitative analysis of biofilm formation, $125 \mu \mathrm{L}$ of the sample was transferred to a new microtiter plate and was measured with micro Elisa auto reader at $492 \mathrm{~nm}$. Biofilm formation ability was classified according to Møretrø et al. (2003). The sample was classified as weak biofilm former if $\mathrm{A}_{492}<0,20$; medium former if $0.20 \leq \mathrm{A}_{492} \leq 1.0$; and strong former if $\mathrm{A}_{492}>1.0$. Based on the ability to resist cooper and to form a biofilm, the four selected isolates were identified based on their molecular characteristics.

\subsection{Molecular identification of copper-resistant and biofilm forming bacteria}

The isolates were identified by $16 \mathrm{~S}$ ribosomal RNA gene sequencing as follows. Pure Culture of Copper-Resistant Bacteria was grown overnight in LB broth for isolation of genomic DNA by using Promega Wizard Genomic DNA Purification Kit (Promega, Madison, WI). 16S rDNA was amplified by using the universal bacterial $16 \mathrm{~S}$ rDNA primers. Two primers corresponding to Escherichia coli positions 27F (5'-AGAGTTTGA TCCTGGCTC-3') and 1492R (5'-GGTTACCTTGTTACGACT-3') were used for PCR amplification of the $16 \mathrm{~S}$ ribosomal RNA (18). The PCR reaction mixture $(25 \mu \mathrm{L})$ consisted of $1 \mu \mathrm{L}$ of DNA template, Ready to Go Mixture PCR, $22 \mu \mathrm{L}$ of nucleasefree water, $1 \mu \mathrm{L}$ of primer $27 \mathrm{~F}(10 \mathrm{pmol} / \mu \mathrm{L})$ and $1 \mu \mathrm{L}$ of primer $1429 \mathrm{R}(10 \mathrm{pmol} / \mu \mathrm{L})$. The $16 \mathrm{~S}$ rRNA gene was amplified using 35 -cycle PCR (initial denaturation), $95^{\circ} \mathrm{C}$ for $5 \mathrm{~min}$; subsequent denaturation, $94^{\circ} \mathrm{C}$ for $30 \mathrm{~s}$; annealing temperature, $52^{\circ} \mathrm{C}$ for $1 \mathrm{~min}$; extension temperature, $72^{\circ} \mathrm{C}$ for $1 \mathrm{~min}$ and the final extension was carried out at $72^{\circ} \mathrm{C}$ for $5 \mathrm{~min}$, followed by a $4^{\circ} \mathrm{C}$ hold. The PCR amplification products were analyzed by electrophoresis on a $1.5 \%$ agarose gel. The appearance of $1.5 \mathrm{~kb}$ band showed that 16S rDNA had been amplified and ready for sequencing. Sequencing was carried out at Genetic Science Malaysia. DNA Sequence Similarity and Phylogenetic Analysis GenBank BLAST (N) was used for homology searches. Molecular evolutionary and phylogenetic analyses were conducted using MEGA version 6 (Tamura et al. 2013).

\section{Results and discussion}

\subsection{Biofilm qualitative analysis by SEM}

Visual examination using SEM is a well-established basic method to observe the morphology of bacteria adhered to material surfaces, the morphology of the material surface, and the relationships between them. This study showed that four isolates produced Extracellular Polymeric Substance (EPS). EPS or biofilm matrix is the main precondition for biofilm formation (Figure 1). SEM images show attachment and initiation of biofilm formation by C53 isolate which was thicker than the other isolates. Biofilm formation is significantly more resistant to environmental 


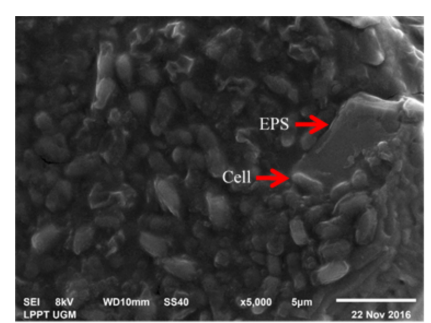

(a)

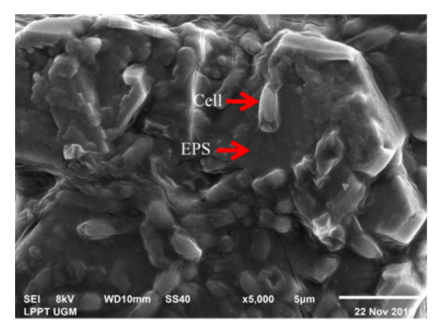

(b)

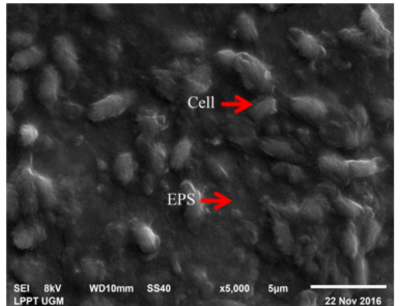

(c)

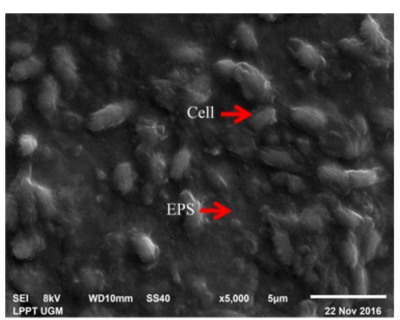

(d)

FIGURE 1 Biofilm formation by C53 isolate (a); C38 isolate; (b) C40 isolate; (c) C43 isolate and (d) C53 isolate that was analyzed using Scanning electron microscopy (SEM). All isolates produce EPS matrix around their cells that enable bacterial cell aggregation.

stresses or microbially deleterious substances than planktonic cells (Annous et al. 2009).

A biofilm is a group of microorganisms in which cells stick to each other on a surface. These adherent cells are frequently embedded within a self-produced matrix of EPS. EPS contributes to protect cells from hostile environments and can bind significant amounts of heavy metals. The composition of EPS depends on the present microorganisms, temperature, and availability of nutrients. The biofilm formation by these strains is considered a natural strategy to maintain a favorable niche in stressful environments with increased metals concentrations (Annous et al. 2009; Cabarkapa et al. 2013).

As reported by Workentine et al. (2008), the biofilm may reduce metal toxicity by altering bacterial physiology to protect the sensitive chemical targets of the reactive metal species. Upon metal binding, the concentration of the free toxic ions in the cytoplasm is minimized. Biosorption of toxic metals is known from cell membranes, cell walls and EPS of biofilms. For example, the EPS matrix and the contained polysaccharides were reported to bind heavy metals. Thus, the metal tolerance of the bacteria belonging to that biofilm was enhanced (Annous et al. 2009; Meliani and Bensoltane 2016).

\subsection{Quantitative analysis of biofilm formation}

Analysis of copper resistance is not always parallel with the ability to form a biofilm. Therefore, all isolates showed high potency as copper-resistant bacteria when tested using the Microtiter plate biofilm assay (Figure 2). The result showed that the biofilm formation on different isolates varied with time. After $48 \mathrm{~h}$ all isolates were found to produce biofilm. The readings of $\mathrm{A}_{492}$ at time 48 $\mathrm{h}$, for C38, C40, C43 and C53 isolates were 0.81, 0.83, 0.72 , and 1.2 respectively. According to Møretrø et al. (2003), the readings of A492 at time 72 hours, C53 Isolate can be categorized as strong biofilm former (1.3), and 3 isolates (C38, C40, and C43) as medium biofilm former (0.93, 0.92, and 0.88, respectively).

The time course for attachment varies depending on the organism and must be determined empirically, although when using this system, many organisms commonly studied will form a biofilm within $48 \mathrm{~h}$ (Merritt et al. 2011). In this research, isolates formed a biofilm at $48 \mathrm{~h}$. The highest absorbance value of the isolates was at $72 \mathrm{~h}$ and the highest descendance value was at $96 \mathrm{~h}$.

Bacteria that form biofilm are known to possess greater resistances to stress conditions than their planktonic counterparts that dispersed in the environment, including the susceptibility to sanitizers and other antimicrobials (D’Souza et al. 2014; Tang et al. 2012). Biofilm is formed when bacterial cells attach to one another and/or adhere to a living or inert contact surface. The attached bacterial cells are enclosed in a self-produced polymeric matrix. The organisms can increase their ability to colonize and survive in a harsh environmental condition if they are able to form this biofilm (Monier and Lindow 2003; Tang et al. 2012).

Biofilm growth and its adhesion are mutually dependent processes, increase consistency with biofilm maturation process. The dispersion of microorganisms from biofilm can be defined as a kind of adaptive response to the conditions present in the environment in which biofilm is developing, for instance, as the adaptive response to the starvation condition (Alipour et al. 2009). The application of the same treatment to bacterial population suspended in the liquid media does not cause activation gene. The resistance of the bacteria in the biofilm is most probably the consequence of the activity of several rather than a single mechanism (Cabarkapa et al. 2013). The results showed that the isolates had the potential to form biofilm and remove copper from the contaminated environment.

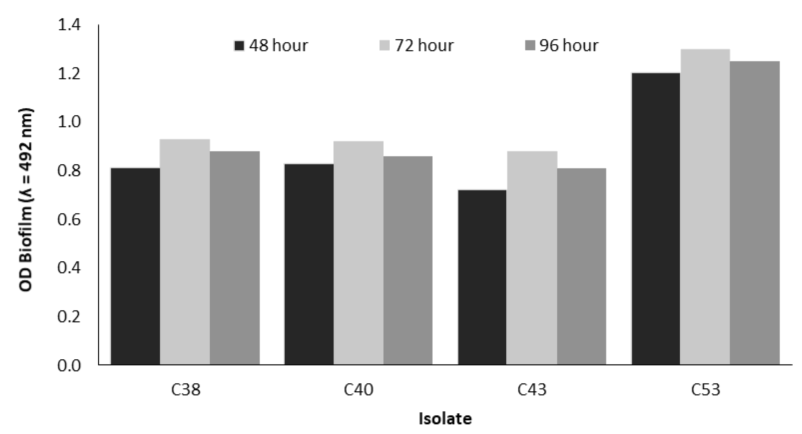

FIGURE 2 The result of biofilm formation ability by copperresistant bacteria that was tested in LB medium at $30^{\circ} \mathrm{C}$, at 48 , 72 and 96 hours. 


\subsection{Molecular identification of copper-resistant bacte- ria}

The bacterial isolates were selected based on their high concentration of copper resistance were identified by $16 \mathrm{~S}$ rRNA gene sequence analysis. Nucleotide sequences were used for GenBank blast analysis and construction of the phylogenetic tree. The Gene of 16S rRNA was amplified using universal primer set ( $27 \mathrm{f}$ and $1492 \mathrm{r}$ ), with PCR product of $1500 \mathrm{bp}$ in size.

The phylogenetic tree showed evolutionary distance among copper-resistant bacteria based on 16S rRNA gene sequence (Figure 3). The phylogenetic tree showed that C38 isolate and Bacillus cereus strain HG10 were clustered together with a bootstrap support of $97 \%$, and a strong bootstrap support of $100 \%$ with Bacillus cereus strain HM85. B. cereus strain HG10 was isolated from activated sludge and B. cereus strain HM85 was isolated from polluted heavy metal soil.

C43 Isolate formed a clade with Bacillus subtilis strain Kakrayal_1 with a bootstrap support of 79\% and a strong bootstrap support of $100 \%$ with B. subtilis strain EN16. Bacillus is an important bacterial genus for bioremediation of heavy metals in different heavy metal contaminated areas. B.subtilis strain Kakrayal_1 was isolated from water environmental and B. subtilis strain EN16 was isolated from soil.

C40 Isolate formed a clade with Lycinibacillus fusiformis strain KWW 111 with a bootstrap support of $76 \%$ and a strong bootstrap support of $100 \%$ with $L$. fusiformis strain MB-52. L. fusiformis strain KWW 111 was isolated from sedimentation basin of the water system and $L$. fusiformis strain MB-52 was isolated from biofilms in chlorinated drinking water systems.

C53 Isolate formed a clade with Pseudomonas aeuruginosa strain Mx1 with a bootstrap support of $77 \%$ and a strong bootstrap support of $100 \%$ with $P$. aeu- ruginosa strain GGRJ21. P. aeuruginosa strain Mx1 is a dichloro propionate-degrading bacteria. P. aeuruginosa strain GGRJ21 was isolated from soil rhizosphere. C53 isolate can be categorized as a strong biofilm former. As the adaptive response to the starvation conditions, $P$. aeuruginosa cells produce the alginate lyase enzyme that dissolves alginate, namely the biofilm polysaccharide (Alipour et al. 2009).

The identity of selected isolates was based on $16 \mathrm{~S}$ rRNA gene sequence analysis (Table 2). C38 isolate had 99\% similarity to B. cereus strain HM85. C43 Isolate had 99\% similarity to B. subtilis strain EN16. C40 Isolate had 99\% similarity to L. fusiformis strain MB52 and C53 isolate had $98 \%$ similarity to $P$. aeuruginosa strain GGRJ21. The sequences of the isolates have been submitted to the GenBank via the submission portal and every isolate had an accession number (Table 2).

In the environmental conditions, bacteria are capable to develop diverse mechanisms as adaptive responses, which enable them to adapt to new environmental conditions such as DNA damages, temperatures, starvations, oxidative stresses, and low water activities. This type of adaptive responses has been characterized in details as the bacteria suspended in liquid media, and it is most probable that such adaptations are present in the bacterial biofilm. Catalase production in $P$. aeruginosa via the activation of Kat B-inducible gene in the response to the treatment with $50 \mathrm{mM}$ of hydrogen peroxide is one of the simple examples of adaptive responses caused by changes of the environmental conditions (Cabarkapa et al. 2013). The genome-wide transcriptional response of copper-adapted and copper-shocked $P$. aeruginosa cultures has revealed a core set of genes comparably regulated under both conditions (Teitzel et al. 2006). This core set includes different transport genes suggesting that copper tolerance is mainly achieved by copper efflux. A CueR-like regulator acti-

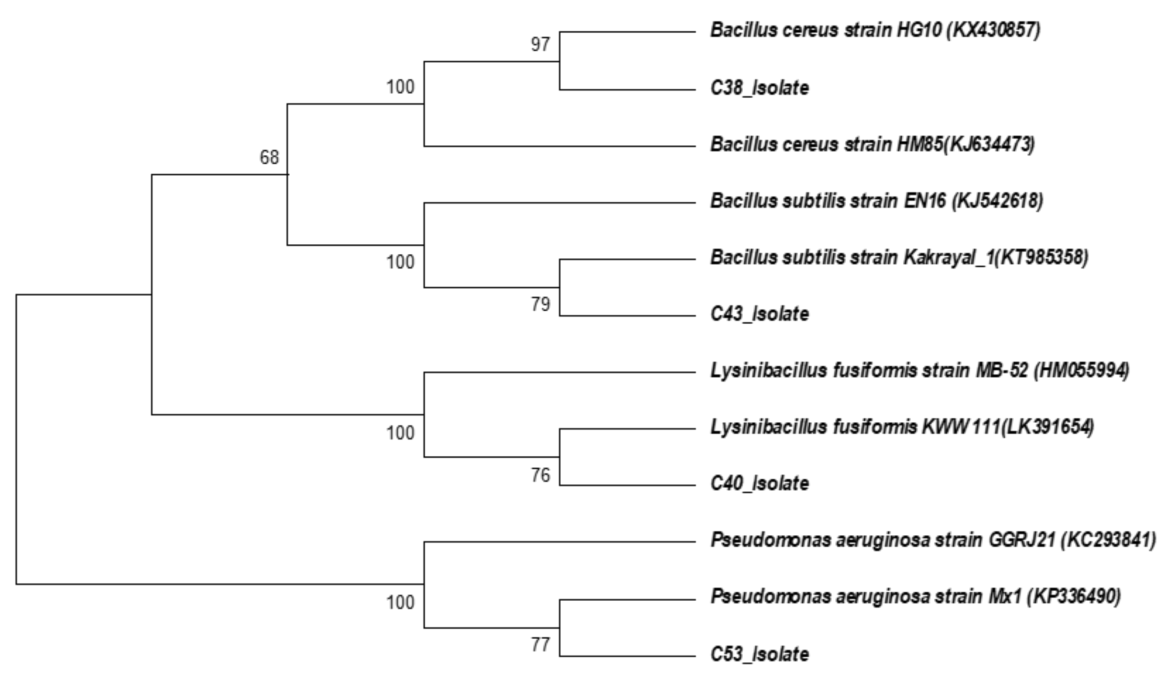

FIGURE 3 Phylogenetic tree shows evolutionary distance among copper-resistant bacteria based on16S rRNA gene sequence. The number at each node is the bootstrap from 100 replicates. The scale is the evolutionary distance value. 
TABLE 2 The closest phylogenetic relatives of bacterial isolates from PT Freeport Indonesia's tailings.

\begin{tabular}{lllll}
\hline Isolate & Acession Number & Closest comparison isolate & GenBank Match & Identity (\%) \\
\hline C38 & MF521959 & Bacillus cereus strain HM85 & KJ634473 & 99 \\
C40 & MF521962 & Lycinibacillus fusiformis strain MB-52 & HM055994 & 99 \\
C43 & MF521960 & Bacillus subtilis strain EN16 & KJ542618 & 99 \\
C53 & MF521963 & Pseudomonas aeuruginosa strain GGRJ21 & KC293841 & 98 \\
\hline
\end{tabular}

vates transcription of several target genes, including cueA, upon copper addition (Thaden et al. 2010; Rademacher and Masepohl 2012).

The monocistronic $c s o R$ gene is localized directly upstream of the copZA operon in $B$. subtilis, which encodes a copper chaperone and a copper-ATPase (Smaldone and Helmann 2007). csoR represses copZA transcription at low copper concentrations by binding a palindromic sequence (TACCCTAC-N4-GTATGGTA) overlapping the copZ promoter. $c s o R$ is no longer binds the promoter and transcription are relieved at elevated copper concentrations. In a mutant which lacks of $c S O R$ repressor, the copZA operon is constitutively transcribed (Rademacher and Masepohl 2012).

Gram-negative and Gram-positive bacteria utilize copper-ATPases as principal defense determinants to excrete excess copper from the cytoplasm. Copper- resistanat bacteria examined so far induce ATPase expression, and different species utilize functionally and structuraly different regulators to control ATPase gene transcription. Under copper-limiting conditions, gram-positive bacteria repress transcription, and Gram-negative bacteria activate ATPase gene transcription (Rademacher and Masepohl 2012).

C38, C40, C43, dan C53 isolates were indigenous bacteria from tailings which contain copper. The isolates can form biofilm and also developed resistance mechanism by accumulating copper. The ability of the isolates to accumulate copper was higher than previously known copperresistant bacteria. B. pumilus and Bacillus sp. isolated from copper mining waste grew up in $300 \mathrm{mg} / \mathrm{L}$ of $\mathrm{Cu}(\mathrm{II})$ (Andreazza et al. 2011). These mechanisms could be utilized for detoxification and removal of copper or the other heavy metal from polluted environmental. Therefore, the next research is encouraged to know the mechanisms of isolates for reducing or detoxification of heavy metals.

\section{Conclusions}

The main Based on 16S rRNA gene sequence analysis: C38 isolate had 99\% similarity to B. cereus strain HM85. C43 isolate had 99\% similarity to B. subtilis strain EN16. C40 isolate had $99 \%$ similarity to $L$. fusiformis strain MB52 and C53 isolate had 98\% similarity to P. aeuruginosa strain GGRJ21. All of the isolates had biofilm forming ability which isolate $\mathrm{C} 53$ can be categorized as a strong biofilm former, and 3 other isolates (C38, C40, and C43) as medium biofilm formers. The capability of C53 isolate to form strong biofilm formation can be exploited in a bioremediation process which aims to remove copper from tailings.

\section{Acknowledgments}

The authors gratefully acknowledge financial support from PT Freeport Indonesia and “Hibah Penelitian Disertasi Doktor” of the Ministry of Research and Technology in 2017.

\section{Authors' contributions}

MM, EM, ES designed the study. MM, EM, RS, TS conducted the field data collection. MM carried out the laboratory work. MM, EM, ES, RS, TS analyzed the data. MM, EM, ES wrote the manuscript. All authors have read and approved the final version of the manuscript.

\section{Competing interests}

The authors declare no competing interest.

\section{References}

Alipour M, Suntres ZE, Omri A. 2009. Importance of dnase and alginate lyase for enhancing free and liposome encapsulated aminoglycoside activity against Pseudomonas aeruginosa. J Antimicrob Chemother. 64:317-325. doi:10.1093/jac/dkp165.

Andersson S, Nilson M, Dalhammar G, Rajaro GK. 2008. Assesment of carrier materials for biofilm formation and denitrification. Vatten 64:201-207.

Andreazza R, Pieniz S, Okeke BC, Camargo FAO. 2011. Evaluation of copper resistant bacteria from vineyard soils and mining waste for copper biosorption. Braz J Microbiol. 42:66-74. doi:10.1590/S151783822011000100009.

Annous BA, Fratamico PM, Smith JL. 2009. Quorum sensing in biofilms: why bacteria behave the way they do. J Food Sci. 74:24-37. doi:10.1111/j.17503841.2008.01022.x.

Cabarkapa I, Levic J, Djuragic O. 2013. Biofilm. In: A Méndez-Vilas, editor. Microbial pathogens and strategies for combating them: science, technology, and education. Badajoz: Formatex Research Center. p. $42-51$. 
Cerca N, Pier GB, Vilanova M, Oliveira R, Azeredo J. 2005. Quantitative analysis of adhesion and biofilm formation on hydrophilic and hydrophobic surfaces of clinical isolates of Staphylococcus epidermidis. Res Microbiol 156(4):506-514. doi:10.1016/j.resmic.2005.01.007.

Chen YQ, Ren GJ, An SQ, Sun QY, Liu CH, Shuang JL. 2008. Changes of bacterial community structure in copper mine tailings after colonization of reed (Phragmites communis). Pedosphere 18(6):731-740. doi:10.1016/S1002-0160(08)60068-5.

Desai C, Jain K, Madamwar D. 2008. Evaluation of in vitro $\mathrm{Cr}(\mathrm{VI})$ reduction potential in cytosolic extracts of three indigenous bacillus sp. isolated from $\mathrm{Cr}(\mathrm{VI})$ polluted industrial landfill. Bioresource Technology 99(14):6059-6069. doi:10.1016/j.biortech.2007.12.046.

D’Souza EL, Meria QGS, Barbosa IM, Athayde AJAA. 2014. Biofilm formation by Staphylococcus aureus from food contact surfaces in a meat-based broth and sensitivity to sanitizers. Braz J Microbiol 45:67-75.

Espírito Santo C, German N, Elguindi J, Grass G, C R. 2014. Biocidal mechanisms of metallic copper surfaces. In: G Borkow, editor. Use of biocidal surfaces for reduction of healthcare acquired infections. Cham: Springer International Publishing. p. 103-136.

Freitas O, Delerue-Matos C, Boaventura R. 2009. Optimization of $\mathrm{Cu}(\mathrm{II})$ biosorption onto Ascophyllum nodosum by factorial design methodology. Journal of Hazardous Materials 167(1):449-454. doi:10.1016/j.jhazmat.2009.01.001.

He Z, Gao F, Sha T, Hu Y, He C. 2009. Isolation and characterization of a cr(vi)-reduction ochrobactrum sp. strain cscr-3 from chromium landfill. Journal of Hazardous Materials 163(2):869-873. doi:10.1016/j.jhazmat.2008.07.041.

Jain AN, Udayashankara TH, Lokesh K. 2014. Review on bioremediation of heavy metals with microbial isolates and amendments on soil residue. Int J Sci Res 3:118-123.

Khusnuryani A, Martani E, Wibawa T, Widada J. 2014. Molecular identification of phenol-degrading and biofilm-forming bacteria from wastewater and peat soil. Indones J Biotechnol. 19(2):99-110. doi:10.22146/ijbiotech.9299.

Massora M, Martani E, Sugiharto E, Sarwom R, Sinaga T. 2016. Isolation and selection of copper-resistant bacteria from PT Freeport Indonesia's tailings. Biotechnology Conference IV. Yogyakarta: UGM Biotechnology Research Center.

Mathur T, Singhal S, Khan S, Upadhyay D, Fatma T, Rat$\tan$ A. 2006. Detection of biofilm formation among the clinical isolates of staphylococci: an evaluation of three different screening methods. Indian J Med Microbiol. 24(1):25-29. doi:10.4103/0255-0857.19890.
Meliani A, Bensoltane A. 2016. Biofilm-mediated heavy metals bioremediation in PGPR Pseudomonas. J Bioremediat Biodegrad. 7(5):1-9. doi:10.4172/21556199.1000370.

Merritt JH, Kadouri DE, O’Toole G. 2011. Growing and analysing static biofilms, current protocols in microbiology. New York: John Wiley \& Sons, Inc.

Monier JM, Lindow SE. 2003. Differential survival of solitary and aggregated bacterial cells promotes aggregate formation on leaf surfaces. Proc Natl Acad Sci USA 100(26):15977-15982. doi:10.1073/pnas.2436560100.

Møretrø T, Hermansen L, Holck AL, Sidhu MS, Rudi K, Langsrud S. 2003. Biofilm formation and the presence of the intercellular adhesion locus ica among staphylococci from food and food processing environments. Appl Environ Microbiol 69(9):5648-5655. doi:10.1128/AEM.69.9.5648-5655.2003.

Osredkar J, Suskar N. 2011. Copper and zinc, biological role and significance of copper/zinc imbalance. J Clin Toxicol. 3:1-18.

Rademacher C, Masepohl B. 2012. Copper-responsive gene regulation in bacteria. Microbiology 158(10):2451-2464. doi:10.1099/mic.0.0584870.

Ratnayake K, Joyce DC, Webb RI. 2012. A convenient sample preparation protocol for scanning electron microscope examination of xylemoccluding bacterial biofilm on cut flowers and foliage. Sci Hortic. 140(Supplement C):12-18. doi:10.1016/j.scienta.2012.03.012.

Roy S, Ganguly S. 2015. Bioremediation activity of microorganisms in soil environment contaminated by heavy metals. J Biol Chem Res. 32:323-330.

Smaldone GT, Helmann JD. 2007. Csor regulates the copper efflux operon copza in Bacillus subtilis. Microbiology 153:4123-4128. doi:10.1099/mic.0.2007/011742-0.

Tamura K, Stecher G, Peterson D, Filipski A, Kumar S. 2013. Mega6: Molecular evolutionary genetics analysis version 6.0. Mol Biol Evol 30(12):2725-2729. doi:10.1093/molbev/mst197.

Tang PL, Pui CF, Wong WC, Noorlis A, Son R. 2012. Biofilm forming ability and time course study of growth of Salmonella typhi on fresh produce surfaces. Int Food Res Journal J 19(1):71-76. doi:10.1128/JB.00837-06.

Teitzel GM, Geddie A, De Long SK, Kirisits MJ, Whiteley M, Parsek MR. 2006. Survival and growth in the presence of elevated copper: Transcriptional profiling of copper-stressed pseudomonas aeruginosa. J Bacteriol. 188(20):7242-7256. doi:10.1128/JB.00837-06.

Thaden JT, Lory S, Gardner TS. 2010. Quorumsensing regulation of a copper toxicity system in pseudomonas aeruginosa. J Bacteriol. 192(10):2557-2568. 
doi:10.1128/JB.01528-09.

Umrania VV. 2006. Bioremediation of toxic heavy metals using acidothermophilic autotrophes. Biores Technol. 97(10):1237-1242. doi:10.1016/j.biortech.2005.04.048.

Workentine ML, Harrison JJ, Stenroos PU, Ceri H, Turner RJ. 2008. Pseudomonas fluorescens' view of the periodic table. Environ Microbiol. 10(1):238-250. doi:10.1111/j.1462-2920.2007.01448.x. 